\title{
TBS, vandaag over gisteren en morgen Een inleiding over het parlementair onderzoek TBS
}

\author{
A.P. Visser ${ }^{*}$
}

\begin{abstract}
Kamerwerk
'Politiek is meesterschap over vorm én inhoud', leerden Frits Bolkestein en Hans Dijkstal me. Een goed politicus zal zich evenzeer in inhoud als in procedures moeten verdiepen om succesvol te zijn. Iedere politieke fractie heeft een eigen cultuur en organisatie waarin de taken zijn verdeeld. Binnen de VVD-fractie was ik tussen 2003 en 2006 woordvoerder 'Asiel en Migratie' binnen de vaste Kamercommissie voor Justitie en woordvoerder 'Hoger Onderwijs en wetenschap' binnen de vaste Kamercommissie voor OCW. Dat was de habitat die ik als Kamerlid kende, zeg maar: asielzoekerscentra en universiteiten. Maar het bracht me ook in Kazakstan voor een raketlancering en in Afghanistan voor een bezoek aan vluchtelingenkampen.
\end{abstract}

Een Kamerlid leidt een chaotisch bestaan met maar enkele vaste momenten. De Kamerweek brengt op dinsdag de wekelijkse fractievergadering in de ochtend, het vragenuur gevolgd door de stemmingen in de middag. En daarna op woensdag debatten, aan het eind van die middag een themavergadering met de fractie en donderdag eventueel weer debatten en commissievergaderingen over de planning van de onderwerpen. Mijn activiteiten bestonden vooral uit lezen, schrijven, praten, werkbezoeken en overleg over aanpalende onderwerpen met fractiegenoten. Dat alles vond plaats binnen vaste afspraken en procedures. Dat is geen eng formalisme. Democratie bestaat bij de gratie van spelregels waaraan iedereen zich houdt.

Arno Visser was van 2003 tot 2006 lid van de Tweede kamer voor de VVD. In 2005/ 2006 was hij voorzitter van de parlementaire enquêtecommissie TBS. 


\section{Parlementair onderzoek}

Het staatsrechtelijke adagium in ons land is: de regering regeert, de Kamer controleert ... achteraf. De uitvoerende macht is dus in handen van Ministers en hun ambtenaren, het parlement ziet toe of de bevoegdheden juist en wenselijk worden toegepast. Daarnaast is het parlement medewetgever. Iedere wet passeert beide Kamers voordat hij van kracht kan worden. Een bijzondere vorm binnen de parlementaire taken en bevoegdheden is het parlementair onderzoek. Bijzonder qua aanpak en bijzonder omdat onderzoekscommissies niet dagelijks worden ingesteld. De onderzoeken gaan dieper in op een thema, een probleem. Maar vooraf is toestemming van de Tweede Kamer als geheel nodig; die geeft een formele opdracht aan een commissie en stelt een budget beschikbaar. Een parlementair onderzoek kan een verandering in de relatie tussen parlement en regering brengen, afhankelijk van het onderwerp: richt het zich op een gebeurtenis uit het verleden of kijkt men naar de toekomst? Richt de commissie zich op de praktijk of op wenselijk beleid?

De onderzoeksopdracht die een commissie krijgt, wordt tevoren vastgesteld door de Kamer na overleg met specialisten. In het geval van het TBSonderzoek gebeurde dat (vertrouwelijk) in de zomer van 2005. Alle fracties deden daar aan mee. Ook het tijdpad en het budget vallen binnen de vastgestelde opdracht. Tegelijkertijd wordt nagegaan wie de Onderzoekscommissie gaan bemannen. Dat gebeurt in het overleg tussen de secretarissen van elke fractie. De Tweede Kamerleden die in de onderzoekscommissie plaatsnemen zijn doorgaans niet de woordvoerders op het onderzoeksterrein, anders zouden zij zichzelf en hun eigen rol onder de loep moeten nemen.

$\mathrm{Na}$ een aantal zeer ernstige incidenten met ontvluchte TBS'ers in de periode 2003-2005, die veel media-aandacht kregen en heftige politieke debatten tot gevolg hadden, besloot de Tweede Kamer een onderzoekscommissie in het leven te roepen die met een brede(re) focus op veiligheid op het terrein van de forensische psychiatrie moest beoordelen of het stelsel van de TBS nog wel voldeed, of dat we een andere koers moesten gaan varen. Na moties van wantrouwen tegen de Minister van Justitie die geen meerderheid haalden, besloten partijen uit oppositie en coalitie - PvdA en VVD - met een motie dat in het TBS-stelsel de onderste steen boven moest komen. 


\section{De onderzoeksopdracht}

In de zomer van 2005 werd de onderzoeksopdracht vastgesteld door de Vaste Kamercommissie voor Justitie en goedgekeurd door de Kamer. Zo'n opdracht is daarmee een gegeven voor de onderzoekscommissie. Die opdracht dient methodologisch te worden gevolgd. Onze opdracht luidde als volgt:

1. Hoe werkt het systeem, hoe kan het worden verbeterd?

2. Wat is al bekend en voorgenomen ten aanzien van het TBS-stelsel en met betrekking tot geestelijk gestoorden die delictgevaarlijk zijn?

3. Welke inzichten levert de analyse op van ontvluchtingen, onttrekkingen en incidenten?

3a. Wat is het effect van categorische maatregelen bij onttrekkingen? $3 \mathrm{~b}$. Zijn het huidige verlofbeleid en de methodiek van verlenging en beëindiging adequaat?

4. Welke problemen zijn te destilleren uit vraag 1 tot en met 3 ?

5. Welke relevante buitenlandse voorbeelden zijn voorhanden?

6. Welke aanpassingen zijn nodig in het systeem?

In de media werden bovenstaande vragen eenvoudig herleid tot de vraag of 'het stelsel op de schop' moest. Maar zo simpel als die vraag kan worden gesteld, zo eenvoudig kan ze niet worden beantwoord. Een brede vraag moet worden 'getrechterd'; de forensische psychiatrie en de TBS zijn ingewikkelde terreinen, met vele spelers uit verschillende disciplines en met eigenstandige verantwoordelijkheden: rechters, advocaten, psychiaters, behandelaren, reclassering, etc. Daarom besloten we ook álle TBS-klinieken te bezoeken.

'Breed onderzoeken en een brede inhoudelijke aanpak', dat was het motto van het parlementair onderzoek naar de TBS. Er zat een lastig probleem aan vast: de commissie communiceert met twee doelgroepen, de sector zelf én het grote publiek. En nog lastiger was het gebrek aan vertrouwen. Het vertrouwen tussen de diverse actoren was zoek. Politiek versus Justitie, departement versus klinieken, klinieken versus GGZ en niet in het minst: het volk in het publiek georganiseerde stelsel. Die laatste relatie was misschien nog wel het belangrijkste. De stelling van de commissie was, dat 'waar grote maatschappelijk onrust heerst, diepgaand parlementair onderzoek op zijn plaats is'. Het is de ultieme taak van de parlementariërs om namens het volk dat ze vertegenwoordigen uit te zoeken wat er aan de hand is. 
Maar onderzoek is één ding; een rapport schrijven een ander. Cruciaal was de vraag hoe je dat 'vertrouwen' terug kon krijgen. Hoe kom je van papier naar praktijk? Hoe zorg je er voor dat alle betrokkenen niet onderdeel van een probleem blijven maar in plaats daarvan onderdeel van een oplossing worden? Dat was te meer relevant aangezien de Tweede Kamer zélf ook onderdeel probleem was. Al die heftige debatten na de incidenten werden vooraf gegaan en gevolgd door vele publicaties in de media. Daarom werd besloten tot een toevoeging aan de onderzoeksopdracht. De Raad voor Maatschappelijke Ontwikkeling (RMO) kreeg de opdracht de rol van de media, de zogenaamde 'mediacratie', nader te beschouwen.

\section{Het rapport: de methode}

Gezien de onderzoeksvraag en vooral gezien de maatschappelijke omstandigheden mocht geen enkele uitkomst vooraf worden uitgesloten. Dus ook niet de conclusie 'dat het TBS-stelsel niet meer voldoet'. Dat was de insteek: met een open instelling en een open blik het TBS-stelsel bezien. Door de veiligheid van de samenleving voorop te stellen beoogden wij het vertrouwen terug te winnen.

Het parlementair onderzoek is als een ijsberg: je ziet 10 procent en de rest is onzichtbaar. Wat de meeste mensen niet zagen was dat het onderzoek uit vele lagen bestond: een deelonderzoek door een onafhankelijk bureau, een deelonderzoek door het RMO, een deelonderzoek door de onderzoekers van het Ministerie Justitie (WODC), een deelonderzoek door het Expertisecentrum Forensische Psychiatrie (EFP), buitenlandse werkbezoeken door de commissie naar Duitsland en het Verenigd Koninkrijk, binnenlandse werkbezoeken door de commissie, besloten gesprekken zowel in het parlement als op locatie, openbare gesprekken (met nieuwe en bekende gesprekspartners), en tot slot het eindrapport waarin alles samen kwam. Al met al een jaar werk.

En let wel: het openbare deel dat dagelijks op televisie werd uitgezonden had een dubbelfunctie. Het was naast 'onderzoek' naar feiten, gebeurtenissen en opinies, ook nog eens openbare 'verantwoording' door de commissie, aan de Kamer en aan het Nederlandse publiek. Iedereen moest zien dat het hier om een transparant proces ging, iedereen moest kunnen zien hoe de commissie tot conclusies kwam, alle partijen moesten in beeld zijn. Alleen met het oog 
op de privacy van de slachtoffers c.q. nabestaanden achtten wij die openbaarheid ongewenst. Daarom werden de gesprekken met bijvoorbeeld de nabestaanden, de vader of de zus van een slachtoffer, vertrouwelijk gehouden. In hun plaats kwam Slachtofferhulp Nederland tijdens het openbare deel in beeld. De keuze was om kwetsbare mensen niet voor oog van de camera te zetten, met alle druk van dien.

\section{Het rapport: de inhoud}

Tijdens een zo breed en veelomvattend onderzoek kom je op veel sporen, waarvan sommige later worden verlaten. Uiteindelijk kwam de commissie met 17 aanbevelingen met betrekking tot wetgeving, beleid, financiering en de uitvoering van het stelsel. Alle actoren kwamen hiermee in beeld. En alles werd gebaseerd en herleid tot waarnemingen en conclusies die voor iedereen te volgen waren geweest.

Voordat die aanbevelingen de revue passeren, maak ik eerst een opmerking vooraf. Tijdens de buitenlandse werkbezoeken werd steeds de vraag gehoord: 'Wat komen jullie hier doen? Jullie hebben het beste systeem, de beste praktijk', gevolgd door de vraag: 'Is het onderzoek mogelijk het gevolg van incidenten die in media zijn uitgesponnen?' Minister Korthals verhaalde tijdens de verhoren ook over het feit dat die politieke aandacht vaak tot averechtse effecten leidt. Men reageert soms te emotioneel. We herinnerden ons dat tijdens de besloten gesprekken wantrouwen, onbegrip en onbekendheid overheersten wanneer actoren over elkaars gedrag spraken. De conclusie van de commissie was dat actie en reactie van onafhankelijke partijen deel van het probleem in de TBS zijn! Dat geldt voor zowel politieke actoren, als de media, maar ook voor Justitie, directeuren van klinieken enzovoort.

Daarnaast was de TBS-problematiek deels bekend door eerder onderzoek, vanuit de zogenaamde Interdepartementale Onderzoeken (IBO 1 en 2) en door de commissie-Kosto. Er was daardoor al eerder een reeks van oplossingen aangedragen. Dat behelsde met name de 'verstopping' van het systeem. Wat voegden wij daar aan toe? Het antwoord op die vraag is vooral zichtbaar in onze analyse van vier lange-termijnontwikkelingen: 
1. de achtergrond van de TBS-ers is veranderd (gelet op diversiteit, culturele achtergrond en combinatiestoornissen) en dat vraagt veel van de professionaliteit van de klinieken;

2. verlof is steeds meer onderdeel van de behandeling geworden;

3. nieuwe risicotaxatie-instrumenten en andere vormen van professionalisering komen op en vertragen de aanvang van het verlof;

4. het preluderen van actoren op elkaars beslissingen.

De laatste ontwikkeling - het vooruitlopen op elkaars reactie - leidde tot de titel van het onderzoeksrapport: Vandaag over gisteren en morgen. Ieder reageert op een ieder, alle beslissingen hangen samen. Een Officier van Justitie preludeert vanwege de publieke druk rond een geruchtmakende zaak, de rechter houdt vervolgens rekening met de capaciteit van een kliniek en met de veiligheid van de samenleving, de Minister wordt terughoudender met verloven door diezelfde publieke druk, de klinieken reageren daar weer op, zij zien ook dat ze een slechte reputatie krijgen in dit geheel en worden voorzichtiger met verzoeken om verlof of beëindiging van de maatregel. Door dit alles neemt de verblijfsduur toe. De advocaten willen vervolgens geen TBS voor hun cliënten, want dat wordt toch maar een eindeloos, uitzichtloos proces, etc., etc. Dit is onderdeel van een breder maatschappelijk proces. Het oordeel van instituties en autoriteiten wordt niet langer geloofd. Moderne massamedia brengen ingewikkelde beslissingen in versimpelde vorm in de huiskamer. Ook TBS-sector ervaart dat.

Van deze vier ontwikkelingen moesten wij komen tot een aanbeveling. Het onderzoeksrapport moest onderdeel van een oplossing worden, tot een begin van het keren van die beweging. Hoe de 'verstopping' van het systeem oplossen? Door onze aanbevelingen zo te structureren dat bij het gemeenschappelijke doel werd begonnen (resocialisatie) en vervolgens terug wordt geredeneerd. Zo moet u de 17 aanbevelingen lezen. Zij staan in onderling verband met elkaar en zijn onlosmakelijk met elkaar verbonden. De 17 aanbevelingen zijn gegroepeerd in vier aandachtsterreinen:

\section{Aanbevelingen gericht op uitstroom}

- verlening voorwaardelijk beëindiging naar 9 jaar

- forensisch psychiatrisch toezicht (klinieken, GGZ, reclassering)

- meer en breder aanbod vervolgtrajecten

- ook 'levenslang' TBS, maar wel differentiatie daarbinnen 
- TBS DBC ontwikkelingen (zorg en veiligheid benoemen, gemeenschappelijk taal ontwikkelen)

\section{Aanbevelingen gericht op uitvoering}

- meer onderzoek risico taxatie

- dwangmedicatie, Bopz

- differentiatie en specialisatie klinieken ontwikkelen (verslaving, psychoten)

- inkopen en niet declareren van plaatsen en behandeling, relatie ministerie tov klinieken anders vastleggen

3. Aanbevelingen gericht op de instroom

- aanpassen TBS met voorwaarden

- culturele factoren in beeld brengen

\section{Aanbevelingen gericht op het TBS als systeem}

- verloftoetsing professionaliseren en anders organiseren

- individuele plaatsing in plaats van aselecte plaatsing

- wetenschappelijk onderzoek

- onderwijs

- PIJ en TBS koppelen t.b.v. ervaringen

- zorg in detentie ontwikkelen

\section{De ontvangst van het rapport}

Het was een bizarre dag. Lang tevoren was de datum vastgesteld. De commissie was trots om sinds lange tijd de eerste onderzoekscommissie te zijn die haar eindproduct op het afgesproken moment aflevert. Dat is wel eens anders. De avond tevoren echter werd plotseling het afscheid aangekondigd van Kamerlid Ayaan Hirsi Ali. De Minister voor Vreemdelingenzaken stelde haar naturalisatie ter discussie. De persconferenties over Ayaans vertrek overschaduwden die van de TBS-commissie, met als gevolg dat wat was begonnen vanuit politieke overbelichting bijna in de achterste kolommen eindigde. Er bestaat zelfs een nooit uitgezonden opname van NOVA, een productie met de commissie in de Pompe-kliniek op de dag van de presentatie. NOVA bleek andere prioriteiten te hebben en wijdde de zendtijd aan een nieuwe rel. 'We hebben geprobeerd de TBS te onthypen. Dat is ons goed 
gelukt,' is mijn standaardantwoord op de terugkerende vraag wat ik vond van die dag.

De kwantiteit van de reacties werd dus beïnvloed door bovenstaande hype, maar de kwaliteit liet niets te wensen over. Actoren als het Ministerie, de GGZ, de reclassering en klinieken reageerden positief, vonden het een goed rapport met bruikbare aanbevelingen, en - niet onbelangrijk - men stak deels de hand in eigen boezem wat betreft het verleden. Het algemene beeld in de reacties vanuit de media was ook positief. 'Uitvoeren de aanbevelingen', schreef een commentator streng. En tot slot de politiek. Ook daar was men over het algemeen zeer positief. Alleen de LPF gaf schoorvoetend toe dat het een goed rapport was maar plaatste er direct kanttekeningen bij. Maar die partij bestaat nu niet meer. Belangrijk was dat het 'vertrouwen' terug leek te zijn. Dat was het sleutelwoord. Vertrouwen in het systeem, vertrouwen tussen actoren onderling. Partijen zagen zichzelf niet meer als onderdeel van een probleem, maar als onderdeel van de oplossing.

De debatten werden eerst gevoerd met de fracties uit de Tweede Kamer onderling. Pas daarna door de Kamer met minister Donner. Immers, een parlementair onderzoek van een speciale commissie moet eerst door het parlement worden overgenomen alvorens het aan de regering wordt voorgelegd. Die twee debatten leken op elkaar. Alle aanbevelingen werden overgenomen door Kamer en Kabinet en vervolgens uitgewerkt in een speciaal 'plan van aanpak' met een flink extra budget.

Hoe gaat het verder? Papier is geduldig. Dat is het grote gevaar achter ieder politiek besluit. Een nog groter gevaar voor de TBS-sector is een terugval in incidentenpolitiek. Geen enkel systeem, geen enkele oplossing kan 100\% veiligheid garanderen. Incidenten zullen er helaas altijd zijn, maar incidentenpolitiek hoeft er niet te zijn en zou moeten worden vermeden. De commissie hoopt ook aan het effectueren van die doelstelling te hebben bijgedragen. 